\title{
OBITUARY
}

\section{Geoff Eustace Blight}

Geoff Blight was no ordinary academic. Six doctoral degrees, over 300 papers in accredited journals, numerous awards and presentation of the Rankine lecture have won Professor Emeritus Geoff Blight the respect of the civil engineering community both at home and abroad.

Geoff was born in the then Northern Transvaal town of Pietersburg, South Africa, on 30 July 1934. On 7 November 2013, the South African geotechnical community received the news of his passing from the Vice-Chancellor of the University of the Witwatersrand (Wits), Geoff's alma mater and the institution to which he devoted most of his 50-odd years in research and academic life.

After obtaining a BSc (civil) engineering degree from Wits in 1955, he spent a short time with the consulting company Kanthack and Partners before returning to Wits to complete his MSc engineering degree in 1958 under Professor Jere Jennings. He was awarded a Witwatersrand University Council scholarship to study overseas and elected do his $\mathrm{PhD}$ at Imperial College under Professor Alan Bishop. His research into the behaviour of partially saturated soils made a significant contribution to this relatively new subject. He earned Bishop's respect for meticulous laboratory testing and, to this day, his thesis provides data that are used by new generations of numerical modellers.

On his return to South Africa, Geoff joined the academic staff at Wits but, after 2 years, he moved on to the National Building Research Institute (NBRI) in Pretoria, where he became a senior research officer. This was around the time that significant advances were being made in our understanding of problem soils including dolomites, heaving clays and collapsible soils, with the NBRI playing a significant role.

In 1969, Geoff was appointed by Wits to the Kanthack chair of civil engineering construction materials. In his introduction to Geoff's Rankine lecture in 1997, John Burland recounted that a condition of Geoff's appointment to this position was that he was not permitted to work on soil mechanics. This was probably an attempt to correct any imbalances that may have occurred during the tenure of Jere Jennings, the previous incumbent of this position. Although this 'infringement of academic liberty', as John Burland put it, was temporary, 'it proved to be a blessing as it compelled him to apply his outstanding practical and scientific talents to other construction materials'. Geoff rose to the challenge and diversified his research activities into other fields of study, including pavement engineering, alkali-aggregate reaction in concrete and solid waste disposal. He also undertook research into pressures on silos and underground ore-passes, which is highly regarded. Even after his subsequent appointment to the Andrew Roberts chair of civil engineering at Wits, where he was again permitted to work in soil mechanics, he maintained this broad focus, particularly in the field of mine tailings and municipal solid waste disposal.

Throughout his career, Geoff was intimately involved with industry. This involvement was not just by way of active participation in various professional and learned societies, but also by consulting to major corporations, mining houses, contractors and engineering consultants. It was this involvement that both prompted and supplied the information for many of his and his graduate students' research efforts. In John Burland's words, 'he used the field as his laboratory'.

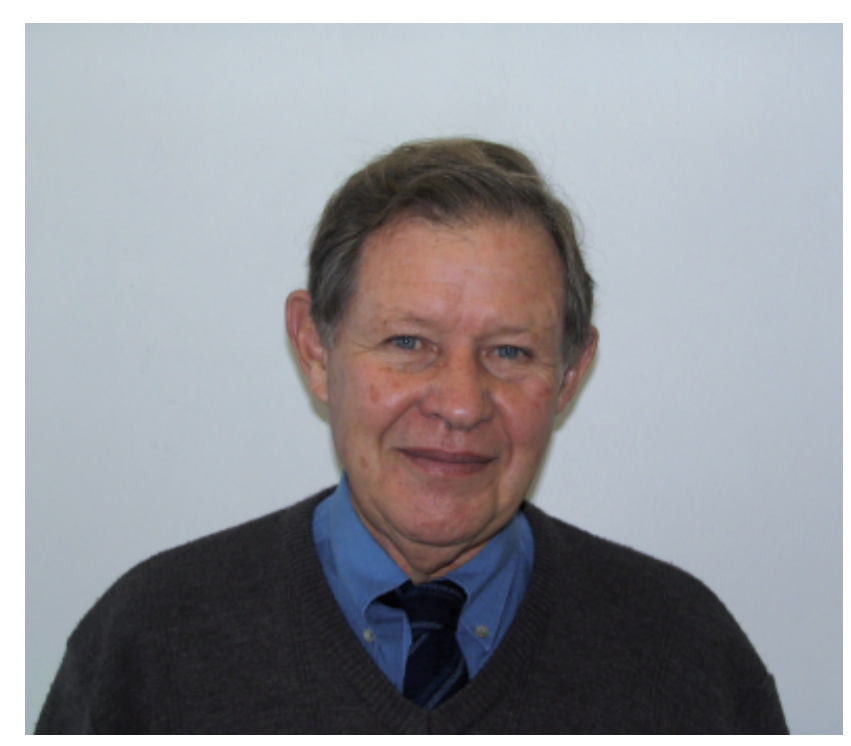

Geoff Eustace Blight (1934-2013)

In 1975, Professor Blight was awarded a DSc(Eng) degree in geotechnical engineering by the University of London, followed by two further DSc(Eng) degrees in 1985 and 1993 from the Wits and the University of Cape Town for contributions to materials engineering and design information from in-situ tests, respectively. In 2001, he was awarded a DEng degree from Wits for the application of research in practice. Finally, in 2009, he was awarded an honorary doctorate in engineering by Wits, the university's highest honour. In his citation, Professor Yunus Ballim wrote

Geoff has always stuck to the fundamentals in his research activities. He excelled as a teacher and particularly as a supervisor and mentor to senior students and emerging academics. Students remember him as a lucid and challenging teacher who was able to make complex subject material more accessible, with just the right dose of empathy for the needs of his students.

During his career, Geoff published prolifically. His books include Geotechnics of gold mining waste disposal (2002), Assessing loads on silos and other bulk storage structures (2005), Geotechnical engineering for mine waste storage facilities (2010), Alkali-aggregate reaction and structural damage to concrete: engineering assessment, repair and management (2011), Mechanics of residual soils, second edition (2012) and Unsaturated soil mechanics in engineering practices (2013), the latter being completed only a few days before he died. At last count, he had published over 330 papers in accredited journals. Unfortunately, even after considerable efforts, it has not been possible to obtain a complete list of his publications.

For a man of his stature and reputation as a leading academic, his curriculum vitae is a very brief two and a half pages. It does, however, list 16 awards and distinctions. These include the ASCE's J. James Croes gold medal for innovation in research (1975), A-grade researcher status by the South African Foundation for Research Development (1989-2002), distinguished research award by the South 
African Institution of Civil Engineering (1989), the Telford Premium by the British Institution of Civil Engineers (1991), chosen as Rankine lecturer by the British Geotechnical Association (1997), South African geotechnical medal by the South African Institution of Civil Engineering (1997), president's award for exceptional service to the waste management profession by the Institute for Waste Management of Southern Africa (2002) and a commendation from the Italian National Group for Prevention of Hydrogeologic Hazards and research into flow failures of tailings dams (2003). He was elected as a fellow of the Royal Society of Southern Africa (1991), founder member of the South African Academy of Science (1991), founder member of the South African Engineering Academy (1991), honorary fellow of the South African Institution for Civil Engineering (1997) and life member of the ASCE (2000).

Professor Blight was always very active in the international community, participating in the work of the UK Institution of Structural Engineers, the International Federation of Chemical Engineers, the International Commission on Large Dams and the International Solid Waste Association. He was a member of the International Society for Soil Mechanics and Geotechnical Engineering technical committees on tailings dams, unsaturated soils, residual soils (former chairman) and erosion of soils. He served as a member of the International Commission on Large Dams (19852000) and the International Solid Waste Association's working group on sanitary landfills (1990-2000), co-authoring the working group's paper on 'Application of graded standards to landfilling in developing countries'. In South Africa, he will be remembered for his contributions to the Minimum requirements for waste disposal by landfill published by the Department of Water Affairs and Forestry and for the Guideline to design and construction of mine waste disposal systems published by the Chamber of Mines, South Africa.

During his time as an academic at Wits, Professor Blight served as dean of the faculty of engineering, deputy dean and assistant dean (postgraduate affairs) and two terms as head of the department of civil engineering. Following his official retirement in 2002, he continued his association with the university as an emeritus professor, directing research and supervising postgraduate students well into his final months.

Professor Geoff Blight will be remembered by his many students at Wits as a quietly spoken man with huge intellectual capacity. He will be sorely missed by colleagues in academic, research and industry circles. Geoff leaves his wife Rhona, son Geoff and daughters Jennifer, Catherine and Barbara.

P. Day, University of Stellenbosch, South Africa M. Gohnert, University of the Witwatersrand, South Africa J. Burland, Imperial College London, UK

\section{REFERENCES}

Blight, G. E. (1979). Guideline to design and construction of mine waste disposal systems. Johannesburg, South Africa: Chamber of Mines.

Blight, G. E. (1997). Interaction between the atmosphere and earth, 37th Rankine Lecture. Géotechnique 47, No. 4, 715-767, http:// dx.doi.org/10.1680/geot.1997.47.4.715.

Blight, G. E. (2005). Assessing loads on silos and other bulk storage structures: research applied to practice. Leiden, the Netherlands: CRC Press.

Blight, G. E. (2010). Geotechnical engineering for mine waste storage facilities. Leiden, the Netherlands: CRC Press.

Blight, G. E. (2013). Unsaturated soil mechanics in geotechnical practice. Leiden, the Netherlands: CRC Press.

Blight, G. E. \& Alexander, M. G. (2011). Alkali-aggregate reaction and structural damage to concrete: engineering assessment, repair and management. Leiden, the Netherlands: CRC Press.

Blight, G. E. \& Leong, E. C. (2012). Mechanics of residual soils, 2nd edn. Leiden, the Netherlands: CRC Press.

Blight, G. E. \& Steffen, O. K. H. (2002). Geotechnics of gold mining waste disposal. Reston, VA, USA: ASCE.

Department of Water Affairs \& Forestry (2005). Minimum requirements for waste disposal by landfill, 3rd edn, Waste Management Series. Pretoria, South Africa: Department of Water Affairs \& Forestry.

Gohnert, M. (2013). Obituary Geoff Blight, Professor Emeritus. Civil Engineering, SAICE 21, no. 11, 86-87. 